\title{
Veterinary antibiotic oxytetracycline's effect on the soil microbial community
}

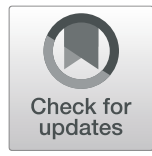

Natalia Danilova*, Polina Galitskaya and Svetlana Selivanovskaya

\begin{abstract}
Background: Antibiotics are widely used to treat animals from infections. After fertilizing, antibacterials can remain in the soil while adversely affecting the soil microorganisms. The concentration of oxytetracycline (OTC) in the soil and its effect on the soil microbial community was assessed. To assess the impact of OTC on the soil microbial community, it was added to the soil at concentrations of 50,150, and $300 \mathrm{mg} \mathrm{kg}^{-1}$ and incubated for 35 days.

Results: The concentration of OTC added to the soil decreased from 150 to $7.6 \mathrm{mg} \mathrm{kg}^{-1}$ during 30 days of incubation, as revealed by LC-MS. The deviations from the control values in the level of substrate-induced respiration on the 5 th day of the experiment were, on average, 26, 68, and 90\%, with OTC concentrations at 50, 150, and $300 \mathrm{mg} \mathrm{kg}^{-1}$, respectively. In samples with 150 and $300 \mathrm{mg} \mathrm{kg}^{-1}$ of OTC, the number of bacteria from the $3 r d$ to 14 th day was $2-3$ orders of magnitude lower than in the control. The addition of OTC did not affect the fungal counts in samples except on the 7th and 14th days for the 150 and $300 \mathrm{mg} \mathrm{kg}^{-1}$ contaminated samples. Genes tet( $(M)$ and tet $(X)$ were found in samples containing 50, 150, and $300 \mathrm{mg} \mathrm{kg}^{-1}$ OTC, with no significant differences in the number of copies of tet( $(\mathrm{M})$ and tet $(X)$ genes from the OTC concentration.
\end{abstract}

Conclusions: Our results showed that even after a decrease in antibiotic availability, its influence on the soil microbial community remains.

Keywords: Antibiotics, Tetracyclines, Antibiotic-resistant genes, Soil microbial biomass, Soil microbial community, Oxytetracycline

\section{Background}

Antibiotics are medicines that are widely used to treat and prevent bacterial infections not only in human medicine but also in veterinary treatments (Sarmah et al. 2006; Thiele-Bruhn 2003). Additionally, in animal husbandry, antibiotics are often used for the growth stimulation of animals (Halling-Sorensen et al. 1998). Many antibiotics used for veterinary purposes are poorly absorbed in the animal's gut, so up to $90 \%$ of the administered dose is excreted in manure or urine (Sarmah et al. 2006). The use of manure as a component of organic fertilizer leads to the spread of antibiotics and antibiotic-resistant genes in the environment (Ramaswamy et al. 2010).

\footnotetext{
* Correspondence: natasha-danilova91@mail.ru

Institute of Environmental Sciences, Kazan Federal University, Kazan 420008,
} Russia

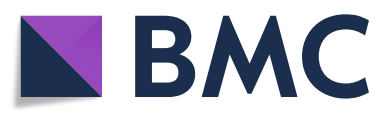

() The Author(s). 2020 Open Access This article is licensed under a Creative Commons Attribution 4.0 International License, which permits use, sharing, adaptation, distribution and reproduction in any medium or format, as long as you give

appropriate credit to the original author(s) and the source, provide a link to the Creative Commons licence, and indicate if changes were made. The images or other third party material in this article are included in the article's Creative Commons licence, unless indicated otherwise in a credit line to the material. If material is not included in the article's Creative Commons licence and your intended use is not permitted by statutory regulation or exceeds the permitted use, you will need to obtain permission directly from the copyright holder. To view a copy of this licence, visit http://creativecommons.org/licenses/by/4.0/. groups; therefore, the relative abundance and diversity of soil microbial species may be damaged (Grenni et al. 2018). It has been reported that some antibiotics inhibit microorganisms, while others have stimulating effects on microbial growth and activity (Sarmah et al. 2006; Thiele-Bruhn 2003; Halling-Sorensen et al. 1998). As a result of the action of the antibiotic as an antimicrobial agent, the biomass of sensitive microorganisms can be reduced. However, there is evidence that some microorganisms are able to use the antibiotic as a carbon source for nutrition, which is expressed in increasing microbial biomass (Thiele-Bruhn and Beck 2005).

Antibiotics have a selective effect on different microbial populations, which leads to the formation of resistance, genetic and phenotypic differences and changes in the relative abundance of microbial species and the 
disruption of the interactions between the various species. As a result, the presence of antibiotics can lead to the disruption of natural environmental processes such as methanogenesis, nitrogen transformation, destruction of organic matter, and nutrient cycling (Sarmah et al. 2006).

The effects of the antibiotic depend on the characteristics of the environment that determine its availability. For example, the persistence, transformation, and sorption of antibiotics are highly dependent on soil type, amount of organic matter, $\mathrm{pH}$, humidity, and temperature. It is known that tetracyclines strongly bind to clay soil particles, humic substances, and montmorillonite. However, at certain $\mathrm{pH}$ values, they can be released and have a long-term effect on microorganisms. Additionally, the impact of the antibiotic on microorganisms depends on its concentration. At high concentrations, antibiotics have bactericidal (fatal) and bacteriostatic (growth-inhibiting) effects on bacteria (Mojica and Aga 2011).

Antibiotics can affect the enzyme activity and biomass production of bacterial communities. It has been reported that some antibiotics inhibit microorganisms, while others have stimulating effects on microbial growth and activity (Thiele-Bruhn and Beck 2005).

Antibiotics of the tetracycline group are among the most common and effective drugs for treating beef cattle, poultry, pigs, sheep, and goats from pneumonia, mastitis, salmonellosis, sepsis, genitourinary infections, and diseases of the gastrointestinal tract. The mode of action of tetracyclines is the prevention of the association of aminoacyl-tRNA and ribosomes in bacterial cells and inhibition of the synthesis of bacterial proteins (Chopra and Roberts 2001; Sarmah et al. 2006). Currently, one of the most commonly used antibiotics of the tetracycline group is oxytetracycline (OTC), discovered in 1949 (Qingxiang et al. 2009), and is actively used in agriculture in Russia.

When introduced into the soil, tetracycline differentially influences various microbial groups and functions. As a whole, the presence of tetracyclines in the soil increases the amount of ammonia-oxidizing bacteria (Cao et al. 2016). Gram-positive bacteria are more sensitive to tetracyclines than gram-negative bacteria because tetracycline-resistant bacteria are mostly gram-negative. Gram-negative bacteria are more resistant to antibodies and antibiotics than gram-positive bacteria because they have a largely impermeable cell wall (Hund-Rinke et al. 2004).

Bacteria have developed several ways to resist the action of tetracyclines. Currently, more than 30 various resistant genes have been described in the scientific literature. These genes encode three mechanisms that endow bacteria with antibiotic resistance: active antibiotic efflux $(\operatorname{tet}(\mathrm{A}), \operatorname{tet}(\mathrm{B}), \operatorname{tet}(\mathrm{C}), \operatorname{tet}(\mathrm{D}), \operatorname{tet}(\mathrm{E})$, tet $(\mathrm{G}), \operatorname{tet}(\mathrm{H}), \operatorname{tet}(\mathrm{I}), \operatorname{tet}(\mathrm{J}), \operatorname{tet}(\mathrm{Z}))$, ribosome protection $(\operatorname{tet}(\mathrm{M}), \operatorname{tet}(\mathrm{O}), \operatorname{tet}(\mathrm{S}), \operatorname{tet}(\mathrm{W}), \operatorname{tet}(\mathrm{Q}), \operatorname{tet}(\mathrm{T}))$, and antibiotic detoxification (tet(X)) (Suzuki et al. 2015; Chopra and Roberts 2001). An adaptation and development of antibiotic resistance in soil microorganisms has already been reported for antibiotic-spiked soil samples (Xie et al. 2017).

Despite the fact that antibiotics and resistance genes are recognized as a serious environmental problem and many studies (Martinez 2009; Xie et al. 2017; Sharma et al. 2016) are devoted to assessing their content in water, bottom sediments, and soil and plants, information on the level of their presence in the natural environment in Russia is practically absent.

In this study, OTC concentration decrease in the soil was estimated over 30 days beginning with an initial antibiotic concentration of $150 \mathrm{mg} \mathrm{kg}^{-1}$. The effect of OTC on the microbial community of the soil was also studied during a model experiment, namely, the changes in the soil substrate-induced respiration, as well as the number of bacterial and fungal strains, were evaluated for dynamics for 35 days. We hypothesized that even after OTC concentration decrease in soil, it "post influences" the soil microbial community in the form of continued resistance patterns as well as altered microbial community structure.

\section{Materials and methods}

Luvisol was used as the subject of the study, sampled in the territory of Laishevsky, District of the Republic of Tatarstan. The soil investigated had a $\mathrm{pH}$ value of 5.8 and contained $2.9 \%$ total organic carbon, $0.18 \%$ total nitrogen, $54.5 \%$ sand, $41.2 \%$ silt, and $4.2 \%$ clay. The climate of the study site was temperate continental; soil sampling was carried out in summer. The sampling site was characterized by the absence of any human activity. Soil samples were collected using the "envelope" method; each sample was collected three times. The soil was collected from the top $20 \mathrm{~cm}$ soil layer. After delivery to the laboratory, the collected soil was cleaned of roots, passed through a $2-\mathrm{mm}$ sieve and incubated at room temperature for 1 week while maintaining a moisture capacity of $60 \%$.

To determine the time of OTC concentration decrease upon insertion into the soil, OTC was introduced into the preincubated soil weighing $3 \mathrm{~kg}$ at a concentration of $150 \mathrm{mg} \mathrm{kg}^{-1}$. Contaminated soil was incubated for 30 days at room temperature $\left(20-25^{\circ} \mathrm{C}\right)$ with the maintenance of a $60 \%$ moisture capacity. The content of the antibiotic in the soil was measured on the 1st, 7th, 10th, 15th, 20th, 25th, and 30th day of incubation. Each measurement was performed in three repetitions. 
To assess the effect of antibiotics on the soil microbial community, OTC was added to the preincubated soil weighing $3 \mathrm{~kg}$ to make the following final concentrations: 50, 150, and $300 \mathrm{mg} \mathrm{kg}^{-1}$. Soil without antibiotic application was used as a control. The pot experiment was carried out for 35 days. The level of substrateinduced respiration (SIR) and the number of bacteria and fungi were estimated on the 1st, 3rd, 5th, 7th, 14th, 21 st, 28th, and 35th day of incubation. Each measurement was performed in three repetitions. Soil samples were stored at a temperature of $20-25{ }^{\circ} \mathrm{C}$ with the maintenance of a $60 \%$ moisture capacity.

In this work, OTC was used in a solution form for injection. The antibiotic was introduced into the soil as follows: OTC was mixed with $50 \mathrm{ml}$ of ethanol and added to a small amount of calcined sand; after ethanol evaporation, the sand, evenly contaminated with antibiotic, was added to the soil.

OTC was extracted using the extraction method with some minor modifications (Li et al. 2009). Each sample (0.5 g sample) was ultrasonically extracted for $15 \mathrm{~min}$ in polypropylene centrifuge tubes with $2 \mathrm{ml}$ of $1 / 1(\mathrm{v} / \mathrm{v})$ methanol/EDTA-Mcllvain buffer $(\mathrm{pH}=4.0)$ and centrifuged at $4000 \mathrm{rpm}$ for $10 \mathrm{~min}$. This procedure was repeated three times. Instrumental determinations were performed using an Agilent 1200 LC-MS System (Agilent, USA) equipped with an additional UV detector (365 and $265 \mathrm{~nm}$ wavelength). OTC was detected using a Zorbax SB C18 column and Chemstation software. Water was mobile phase A and acetonitrile was mobile phase $\mathrm{B}$ with a total flow rate of $0.4 \mathrm{ml} \mathrm{min}{ }^{-1}$. The solvents were mixed as follows: $0-7 \mathrm{~min}, 15 \% \mathrm{~A} ; 7.01-9$ $\min , 85 \% \mathrm{~A} ; 9.01-12 \mathrm{~min}, 15 \% \mathrm{~A}$. The \% recoveries of the analyzed antibiotic were between 52 and 56 . The limits of quantification ranged from $20 \mu \mathrm{g} \mathrm{L}^{-1}$ to $100 \mu \mathrm{g}$ $\mathrm{L}^{-1}$. Concentrations of antibiotics in the soil samples were calculated by an external standard method based on the peak area of the monitored production ( $\mathrm{Li}$ et al. 2009).

The evaluation of substrate-induced respiration was conducted according to ISO 14240-1. First, $0.02 \mathrm{~g}$ of Dglucose was added to $0.02 \mathrm{~g}$ of soil, and then the moistened soil was placed in three sacks. A $20 \mathrm{ml}$ solution of sodium hydroxide $(0.05 \mathrm{M})$ was poured into the laboratory flask, and a sack with soil was placed inside the flask. The flask was sealed and incubated for $24 \mathrm{~h}$ at 25 ${ }^{\circ} \mathrm{C}$. After $24 \mathrm{~h}$, the sack was carefully removed, and $2 \mathrm{ml}$ of barium chloride solution $(0.05 \mathrm{M})$ added to precipitate adsorbed $\mathrm{CO}_{2}$ as barium carbonate. Three to four drops of indicator solution (phenolphthalein) were added, and the residual sodium hydroxide content was diluted with dilute hydrochloric acid $(0.1 \mathrm{M})$.

Extraction of DNA from soil samples was carried out using the FastDNA Spin Kit for Soil (MP Bio, Germany) according to the manufacturer's instructions. DNA purification was carried out using the QIAquick PCR Purification Kit (Qiagen, Germany). Detection of the ratio of bacterial and fungal strains was carried out by real-time PCR (ISO 17601:2016) using two pairs of primers 947f/ 1349r and ITS1f/ITS2r with the following sequences: F: AACGCGAAGAACCTTAC, R: CGGTGTGTACAAGG CCCGGGAACG (for bacterial strains); F: TCCGTA GGTGAACCTGCGG, R: GCTGCGTTCTTCATCGAT GC (for fungal strains) (Zhang et al. 2013). The master mix reaction mixture $(25 \mu \mathrm{l})$ contained the following components: DNA template $1 \mu \mathrm{l}$, forward and reverse primers $(10 \mu \mathrm{M}) 0.5 \mu \mathrm{l}$ each, dNTPs $(10 \mu \mathrm{M}) 2.5 \mu \mathrm{l}, 10 \times$ Buffer with SYBR Green $2.5 \mu \mathrm{l}, \mathrm{MgCl}_{2}(25 \mu \mathrm{M}) 2.5 \mu \mathrm{l}$, SynTaq polymerase $\left(5 \mathrm{U} \mathrm{\mu l}^{-1}\right) 0.2 \mu \mathrm{l}$, and $\mathrm{ddH}_{2} \mathrm{O} 15.3$ $\mu \mathrm{l}$. Amplification was performed on a BioRad CFX-96 cycler (BioRad, Germany) using the following temperature program: primary denaturation at $95{ }^{\circ} \mathrm{C}$ for $5 \mathrm{~min}$, then 39 three-step cycles at $62-60{ }^{\circ} \mathrm{C}$ for $45 \mathrm{~s}$, at $95{ }^{\circ} \mathrm{C}$ for $15 \mathrm{~s}$, and at $72{ }^{\circ} \mathrm{C}$ for $30 \mathrm{~s}$. DNA standard curves were constructed using bacteria Pseudomonas putida and micromycete Penicillium notatum.

Detection of two tet genes, tet $(\mathrm{M})$ and tet $(\mathrm{X})$, was carried out by real-time PCR (ISO 17601:2016) using two pairs of primers with the following sequences for tet $(\mathrm{M})$ : F: GGTTGGAATGTGACGGACTG, R: ATCGTTGTAT GCTCGTGAAAGA and tet $(\mathrm{X}) \mathrm{F}$ : GAAAGAGACA ACGACCGAGAG, R: ACACCCATTGGTAA GGCTAAG. In detail, the PCR products of tet(M) and tet $(\mathrm{X})$ were first cloned using the TA Cloning Kit (Invitrogen Corporation, Carlsbad, CA). Then, the plasmids carrying tet $(\mathrm{M})$ and tet $(\mathrm{X})$ were extracted and purified using a PureLink Quick Plasmid Miniprep Kit (Invitrogen Corporation, Carlsbad, CA) (Zhang et al. 2009). The master mix reaction mixture $(25 \mu \mathrm{l})$ contained the following components: DNA template $1 \mu \mathrm{l}$, forward and reverse primers $(10 \mu \mathrm{M}) 0.5 \mu \mathrm{l}$ each, dNTPs $(10 \mu \mathrm{M}) 2.5$ $\mu \mathrm{l}, 10 \times$ Buffer with SYBR Green $2.5 \mu \mathrm{l}, \mathrm{MgCl}_{2}(25 \mu \mathrm{M})$ $2.5 \mu \mathrm{l}$, SynTaq polymerase $\left(5 \mathrm{U} \mathrm{\mu l}^{-1}\right) 0.2 \mu \mathrm{l}$, and $\mathrm{ddH}_{2} \mathrm{O}$ $15.3 \mu \mathrm{l}$. Amplification was performed on a BioRad CFX-96 cycler using the following temperature program: primary denaturation at $95^{\circ} \mathrm{C}$ for $5 \mathrm{~min}$, then 39 three-step cycles at $62-60{ }^{\circ} \mathrm{C}$ for $45 \mathrm{~s}$, at $95{ }^{\circ} \mathrm{C}$ for $15 \mathrm{~s}$, and at $72{ }^{\circ} \mathrm{C}$ for $30 \mathrm{~s}$.

The significances in data were repeatedly tested by ANOVA in R with Tukey Honest Significant Differences test or Student test as post hoc tests. Differences between values at $p<0.001$ were considered statistically significant.

\section{Results}

In the first stage, the time of OTC half-life in soil was investigated. The initial concentration of OTC added to the soil at $150 \mathrm{mg} \mathrm{kg}^{-1}$ was selected on the basis of a 
literature search. The other authors used 1 to $300 \mathrm{mg} \mathrm{kg}^{-1}$ of tetracycline in their studies (Chen et al. 2013; Molaei et al. 2017; Duan et al. 2017). During the 30-day incubation of soil contaminated with antibiotic, the concentration of OTC content was measured by liquid chromatography. The concentration dynamics for OTC is shown in Fig. 1. The OTC concentration on day 30 was approximately $98 \%$ less than that on day 1 .

In the second stage of the study, the effect of OTC at concentrations of 50,150 , and $300 \mathrm{mg} \mathrm{kg}^{-1}$ on the SIR of the soil and the number of bacterial and fungal strains were evaluated. The model experiment was carried out for 35 days because it was previously established that the time of destruction of OTC in the soil during incubation at room temperature and with $60 \%$ moisture is 30 days. The change in the SIR of the soil contaminated with an antibiotic is shown in Fig. 2.

The level of SIR after antibiotic addition significantly decreased from the 1st to the 5th day of the experiment in all three contaminated samples compared with the control. The greatest decrease (7.2 times) was observed in a sample contaminated with $300 \mathrm{mg} \mathrm{kg} \mathrm{g}^{-1}$ OTC. On the 7th day, the SIR level increased again; in the sample with $50 \mathrm{mg} \mathrm{kg}^{-1} \mathrm{OTC}$, it remained comparable to the control until the end of the experiment and in the samples with 150 and $300 \mathrm{mg} \mathrm{kg}^{-1}$ OTC, it was $1.3-2.3$ times higher $(p<0.001)$ and $1.6-2.6$ times higher $(p<$ $0.001)$ than in the control, respectively.

It was suggested that the changes of SIR described were connected with various dynamics of bacterial and fungal communities after addition of the antibiotics. Because OTC is an antibacterial drug, it was assumed that OTC addition, at least in the short term, would lead to a decrease in the bacterial counts in contrast with fungal counts that were expected to maintain or even grow in conditions without high bacterial competition. To verify this assumption, the bacterial and fungal 16S and ITS
rRNA gene copy numbers were estimated using the realtime PCR method. The results obtained are shown in Fig. 3 a, b.

The number of bacterial genes in the control soil was $4.15 \times 10^{7}-2.14 \times 10^{8}$ copies $\mathrm{g}^{-1}$, and the number of micromycete genes was $1.64 \times 10^{4}-6.02 \times 10^{4}$ copies $g^{-}$ ${ }^{1}$. It was revealed that the addition of OTC at a concentration of $50 \mathrm{mg} \mathrm{kg}^{-1}$ had practically no effect on the bacterial counts, while concentrations of 150 and 300 $\mathrm{mg} \mathrm{kg}^{-1}$ significantly affected this parameter $(p<0.001)$. Between the 3rd and 14th days, bacterial counts were $2-3$ orders of magnitude lower than in the control $(p$ $<0.001)$. Furthermore, an increase in bacterial counts was observed, and on the 28th $(p<0.001$ for $150 \mathrm{mg}$ $\mathrm{kg}^{-1} ; p<0.001$ for $\left.150 \mathrm{mg} \mathrm{kg}{ }^{-1}\right)$ and 35th $(p<0.001$ for $150 \mathrm{mg} \mathrm{kg}^{-1} ; p<0.001$ for $150 \mathrm{mg} \mathrm{kg}$ ) days counts exceeded the control by 1-2 orders of magnitude. The antibiotic addition did not affect the fungal counts in the soil samples except for the $150 \mathrm{mg} \mathrm{kg}^{-1}$ on the 14th day $(p<0.001)$ and $300 \mathrm{mg} \mathrm{kg}^{-1}$ on the 7 th $(p<0.001)$ and 14th $(p<0.001)$ days in the experiment contaminated samples.

At the next stage of the study, the quality of tet $(\mathrm{M})$ and tet $(\mathrm{X})$ genes was determined using the real-time PCR method. The results obtained are shown in Fig. 4 a, b.

As shown in Fig. 4, tet $(\mathrm{M})$ and $\operatorname{tet}(\mathrm{X})$ tetracyclineresistant genes were detected in soil samples at all three concentrations of OTC $(p<0.001)$. The tet $(\mathrm{M})$ gene is responsible for the ribosomal protection of the cell from tetracyclines, and the tet $(\mathrm{X})$ deactivates them if they have penetrated into the cell.

Interestingly, various OTC concentrations introduced into the soil did not cause significant differences in the number of resistant genes tet $(\mathrm{M})$ and $\operatorname{tet}(\mathrm{X})$. On the 5th and 7th day of the experiment, the amount of the tet $(\mathrm{M})$ and $\operatorname{tet}(\mathrm{X})$ genes decreased in soil samples with 150 and $300 \mathrm{mg} \mathrm{kg} \mathrm{kg}^{-1}$ OTC. Most likely, the microbial

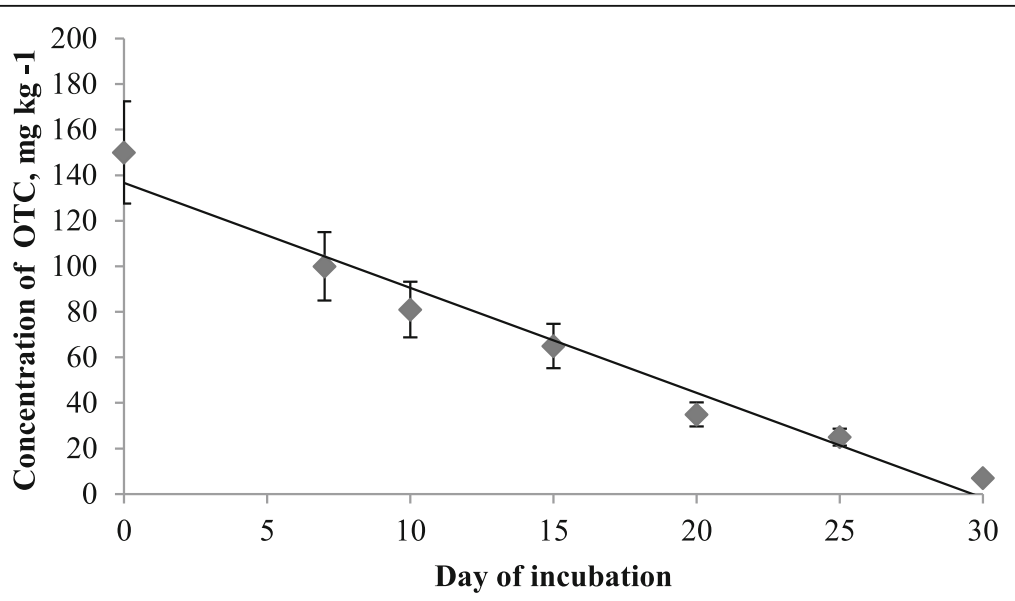

Fig. 1 Concentration of OTC in soil during 30 days of incubation 


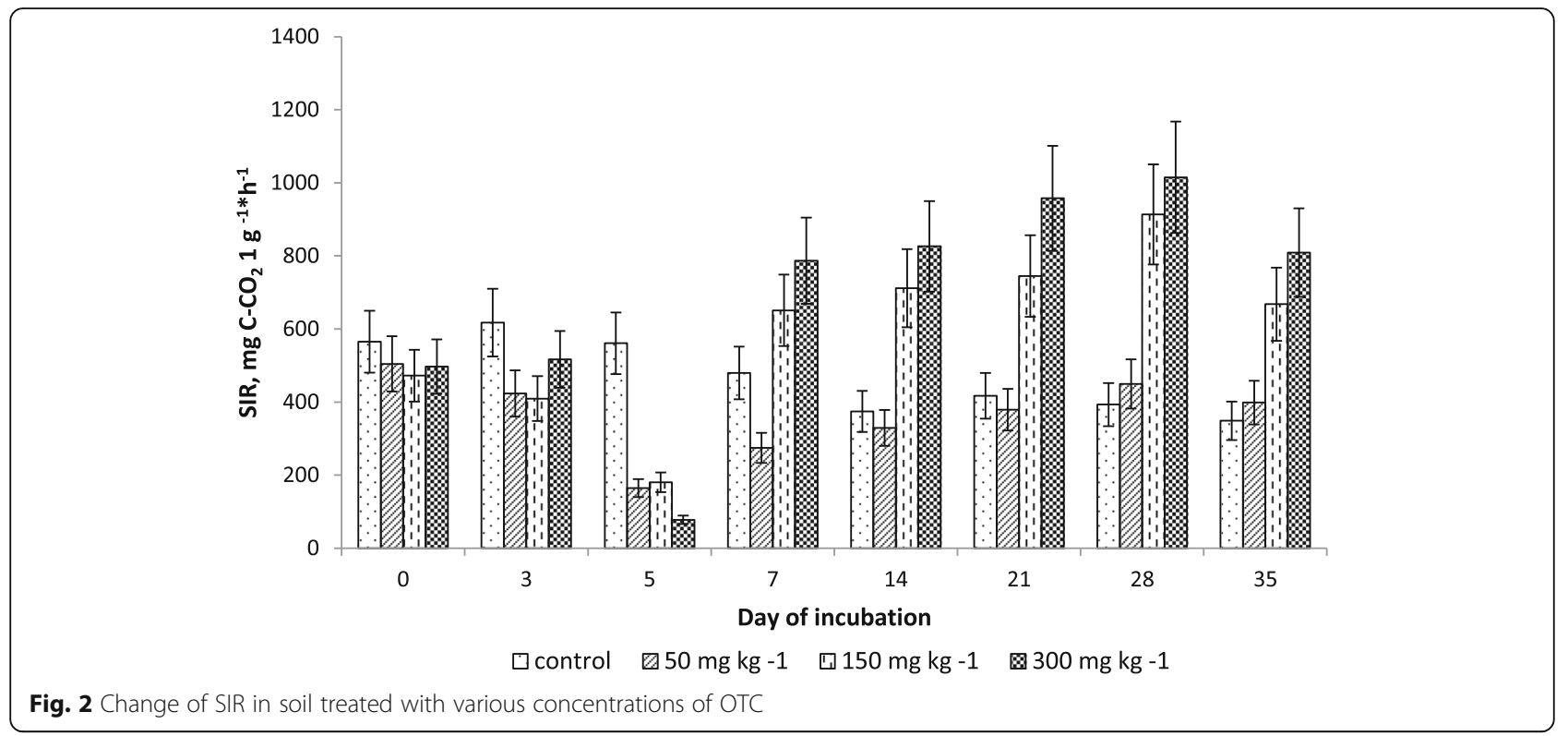

community underwent changes during this period in the presence of an antibiotic added into the soil, associated with a decrease in the level of SIR in these samples.

\section{Discussion}

Due to various physicochemical properties, antibiotics have different half-lives in the soil from several days to several months (Sarmah et al. 2006). According to previous studies, the half-life of OTC in soil ranged between 10 and 79 days (Kay et al. 2004; Wang and Yates 2008; Sarmah et al. 2006). Various rates of antibiotic destruction in soil may depend on its concentration, soil type, quantity of organic matter content, and microbial activity (Sarmah et al. 2006).

When introduced into the soil, antibiotics can disrupt natural processes in soil ecosystems, inhibiting the functioning of microbial communities in soils (Halling-Sorensen et al. 1998). In this case, shifts in the ratio of bacterial and fungal number and changes in soil microbial activity and biomass can occur. Such changes ultimately can affect the fertility of agricultural soils in general (Sarmah et al. 2006).

To assess the effect of antibiotics on the functions of microbial communities of the soil, parameters such as microbial activity, biomass and respiration are measured. It is considered that substrate-induced respiration represents the total microbial biomass (Blagodatskaya and Kuzyakov 2013).

Most likely, during the first 5 days of the experiment, soil microbes that were sensitive to the antibiotic died, which resulted in a decrease in the overall level of SIR. Furthermore, the released ecological niches were taken by species resistant to OTC that multiplied in the absence of competitors, which resulted in an increase in the level of SIR.

The dose-dependent inhibitory effect of the antibiotic on SIR in soil was observed at the initial stage of incubation; however, further recovery of SIR values to the level of the control soil was observed, which may be associated with the formation of resistance to OTC in bacteria and a decrease in the bioavailability of the antibiotic (Thiele-Bruhn and Beck 2005; Speer et al. 1992; Alonso et al. 2001; Roberts 2005; Martinez 2009; Aydin et al. 2015; Munita and Arias 2016; Zhang et al. 2019). In another study, the suppressing effect of tetracycline on SIR was found only at a high dose of antibiotic (500 $\left.\mathrm{mg} \mathrm{kg}^{-1}\right)$; the weak effect of low doses $\left(5 \mathrm{mg} \mathrm{kg}^{-1}\right.$ and $50 \mathrm{mg} \mathrm{kg}^{-1}$ ) was interpreted by a decrease in bioavailability as a result of high sorption of tetracycline in the soil (HundRinke et al. 2004).

The bioavailability of OTC is the highest during the first several days after spiking; therefore, its inhibitory effect is the most pronounced on these days (Molaei et al. 2017). Different authors observed non-linear effects of OTC on soil respiration and biomass. Thus, low (1-15 $\mathrm{mg} \mathrm{kg}^{-1}$ ) and moderate (20-50 $\mathrm{mg} \mathrm{kg}^{-1}$ ) concentrations of OTC were non-inhibitory for these parameters since and OTC was significantly sorbed by the soil particles and even used as a carbon source, while high concentrations (150 mg kg $\mathrm{mg}^{-1}$ and over) led to a decrease in microbial biomass and respiration (Chen et al. 2014; Molaei et al. 2017). Sorption intensity highly depends on soil texture, $\mathrm{pH}$, and other characteristics (Liu et al. 2015). Effects of OTC also may depend on the presence of initial resistance patterns of the soil microbial community. OTC introduced into soil acted as a selective factor for 


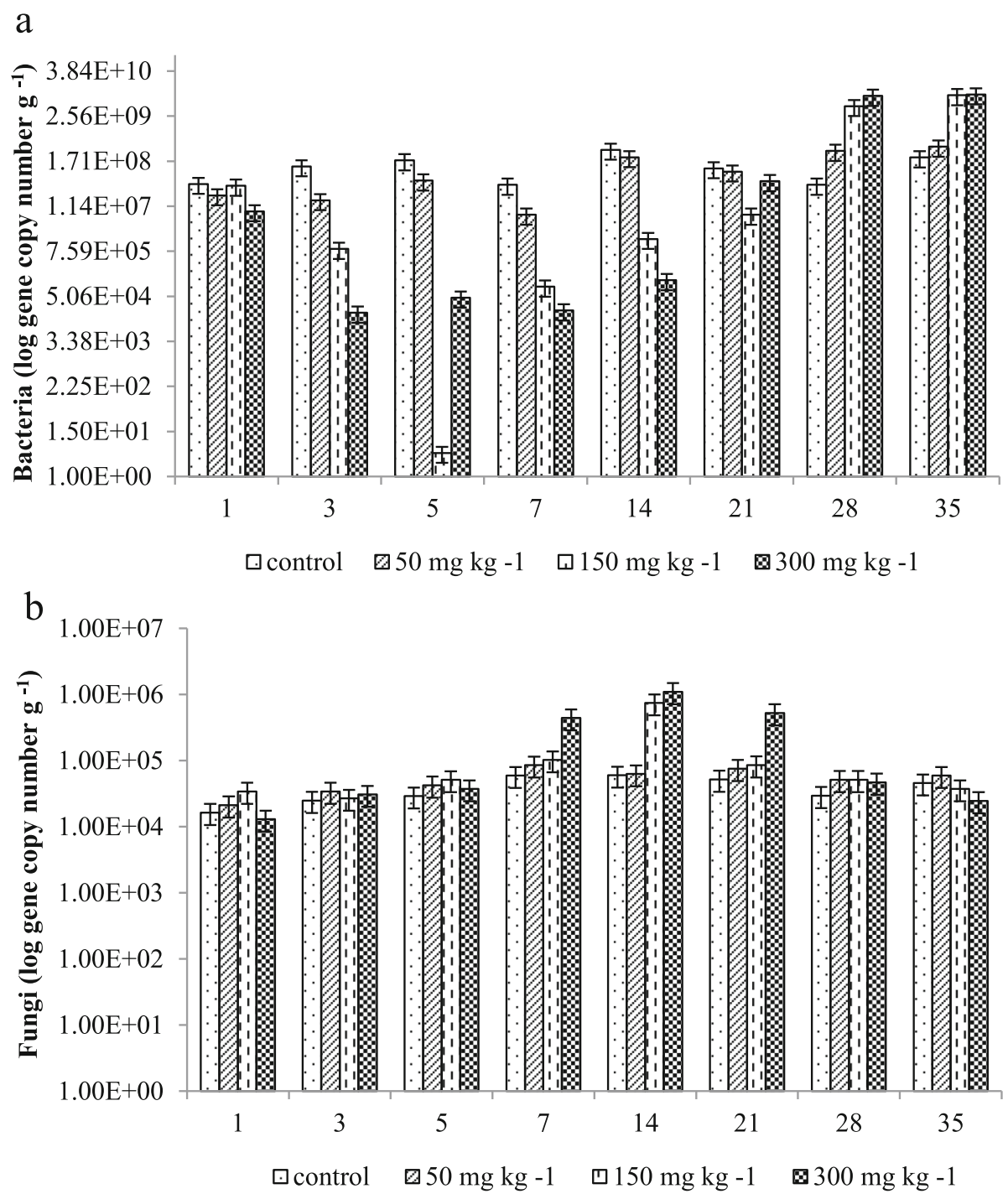

Fig. 3 Number of copies of bacterial (a) and fungal (b) genes in soil contaminated with OTC

resistant microbes and intensified horizontal gene transfer. When the number of resistant bacteria was high, the influence of OTC on soil microbial activity and biomass was negligible (Ma et al. 2016).

In general, the dynamics of the microorganism counts determined by the real-time PCR method correlated with the dynamics of the SIR level. In the first stages, the antibiotic was present in the soil at high concentrations and it negatively affected the sensitive bacterial species; as a result, the counts of bacteria decreased. When the antibiotic concentration decreased, bacterial populations recovered. The number of micromycetes was not directly affected by OTC. In those samples where there was a significant decrease in the bacterial counts, the fungal population grew as a result of weak competition. After the recovery of bacterial populations, the fungi counts returned to the control values. Interestingly, those bacterial counts not only recovered to the control values but even exceeded them. This could be partly explained by the growth of antibiotic-resistant populations (Cheng et al. 2016).

Excessive use of antibiotics in animal husbandry and the subsequent use of livestock waste introduces large amounts of antibiotics and resistant genes into the soil environment ( $\mathrm{Du}$ and Liu 2012). Many studies point to the formation of resistant properties in soil microorganisms when antibiotics enter the soil (Xie et al. 2017; Jechalke et al. 2014; Heuer et al. 2011). There are at least three ways in which antibiotics in manure or compost can increase the abundance of resistant genes in the soil. First, the organic matter of manure or compost can contribute to the 

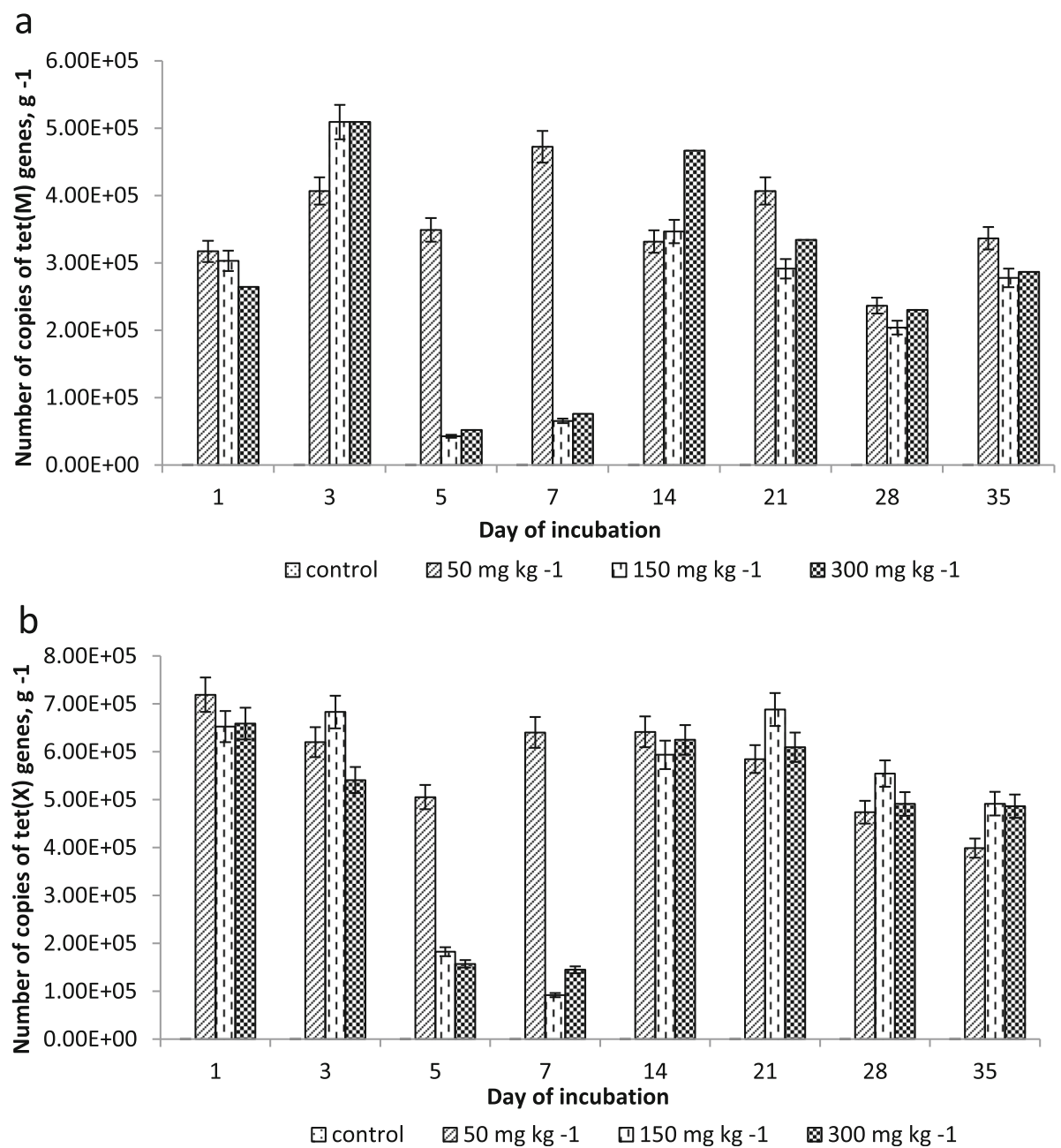

Fig. 4 Number of copies of tet(M) genes, $g^{-1}$ in soil treated with various concentrations of OTC $(\boldsymbol{a})$; Number of copies of tet $(X)$ genes, $\mathrm{g}^{-1}$ in soil treated with various concentrations of OTC (b)

increase in intrinsic resistant genes that are initially present in soil bacteria. Second, resistant genes from manure or compost are introduced directly into the soil and stored in the soil by host bacteria, spreading through horizontal gene transfer. The third way is de novo mutations in the soil by selection for antibiotic resistance due to manure or soil (Xie et al. 2016).

Our results obtained also confirm that soil bacteria can acquire resistance in soil contaminated with antibiotics. In addition, another factor that may indirectly contribute to the spread of antibiotic resistance among microbial communities is the heavy metals that accumulate in the soil after manure treatment (Heuer et al. 2011). Recent studies have shown an increase in the level of antibiotic-resistant genes in soils contaminated with antibiotic-spiked manures and composts or irrigated with water containing antibiotics (Heuer et al. 2011; Wang et al. 2015; Tien et al. 2017).

\section{Conclusions}

In the laboratory experiment, it was shown that OTC concentration, upon introduction into the soil, decreases rather quickly. At an initial concentration of $150 \mathrm{mg} \mathrm{kg}^{-1}$ in the soil, the quantity of the drug reduced by $98 \%$ during the 30-day incubation. The introduction of the antibiotic into the soil at concentrations of 50,150 , and $300 \mathrm{mg} \mathrm{kg}^{-1}$ was accompanied by a partial elimination of bacteria. On the 5 th day of the model experiment, the level of microbial biomass decreased by $26 \%, 68 \%$, and $90 \%$ in soil with a concentration of 50,150 , and $300 \mathrm{mg} \mathrm{kg}^{-1}$, respectively, compared to the reference value. On the 14th day, growth of microbial biomass in contaminated samples was observed. The survival and spread of tetracycline-resistant genes could contribute to bacterial survival in contaminated soil. With a concentration 150 and $300 \mathrm{mg} \mathrm{kg}^{-1}$ of OTC, from the 3rd to the 14th day, a decrease in the number of bacteria was observed by $2-3$ orders of 
magnitude in comparison with the control. OTC had practically no negative effect on the number of fungi in the soil. Simultaneously, with the decrease in the number of bacterial strains, there was a short-term increase in the number of micromycetes, possibly because the fungi occupied the newly vacated ecological niches. Soil contamination with OTC led to the formation of resistance in soil microorganisms. Tetracycline-resistant genes tet $(\mathrm{M})$ and tet $(\mathrm{X})$ were present in soil containing 50,150 , and $300 \mathrm{mg}$ $\mathrm{kg}^{-1}$ OTC. However, there were no significant differences in the number of copies of the tet $(\mathrm{M})$ and $\operatorname{tet}(\mathrm{X})$ genes at various OTC concentrations. We conclude that the effects of OTC introduced into the soil should be estimated based only on the half-life of antibiotics and on the maintenance of the resistance patterns of the microbial community as well as the presence or absence of fungal and bacterial counts. As we demonstrated in this study, the effects of OTC on the microbial community remain longer than the presence of antibiotics.

\section{Abbreviations}

OTC: Oxytetracycline; SIR: Substrate-induced respiration.

\section{Acknowledgements}

Not applicable.

\section{Authors' contributions}

ND and PG participated in the design of the study and conducted field work. ND, PG, and SS analyzed and interpreted the data. ND and PG wrote the manuscript. All authors read and approved the final manuscript.

\section{Funding}

This work was supported by a subsidy allocated to Kazan Federal University from the Russian Foundation for Basic Research, project no 18-29-25054.

\section{Availability of data and materials}

The datasets generated during and/or analyzed during the current study are available from the corresponding author on reasonable request.

\section{Ethics approval and consent to participate}

Not applicable.

\section{Consent for publication}

Not applicable.

\section{Competing interests}

The authors declare that they have no competing interests.

Received: 9 August 2019 Accepted: 25 March 2020

Published online: 07 April 2020

\section{References}

Alonso A, Sánchez P, Martínez JL. Environmental selection of antibiotic resistance genes. Environ Microbiol. 2001;3(1):1-9.

Aydin S, Ince B, Ince O. Development of antibiotic resistance genes in microbial communities during long-term operation of anaerobic reactors in the treatment of pharmaceutical wastewater. Water Res Elsevier Ltd. 2015;83: 337-44.

Blagodatskaya E, Kuzyakov Y. Active microorganisms in soil: Critical review of estimation criteria and approaches. Soil Biol Biochem. 2013;67:192-211.

Chen GX, He WW, Wang Y, De Zou Y, Liang JB, Di Liao X. Effect of different oxytetracycline addition methods on its degradation behavior in soil. Sci Total Environ. 2014;479-480(1):241-6.

Chen W, Liu W, Pan N, Jiao W, Wang M. Oxytetracycline on functions and structure of soil microbial community. J Soil Sci Plant Nutr. 2013;13(4):967-75.
Cheng W, Li J, Wu Y, Xu L, Su C, Qian Y. Behavior of antibiotics and antibiotic resistance genes in eco-agricultural system: A case study. J Hazard Mater. 2016;304:18-25.

Chopra I, Roberts M. Tetracycline antibiotics : mode of action , applications, molecular biology, and epidemiology of bacterial resistance. Microbiol Mol Biol Rev. 2001;65(2):232-60.

Du L, Liu W. Occurrence, fate, and ecotoxicity of antibiotics in agro-ecosystems. A review. Agron Sustain Dev. 2012;32(2):309-27.

Duan M, Li H, Gu J, Tuo X, Sun W, Qian X. Effects of biochar on reducing the abundance of oxytetracycline, antibiotic resistance genes, and human pathogenic bacteria in soil and lettuce. Environ Pollut. 2017;224:787-95.

Grenni P, Ancona V, Barra CA. Ecological effects of antibiotics on natural ecosystems: a review. Microchem J. 2018;136:25-39.

Halling-Sorensen B, Nielsen S, Lanzky PF, Ingerslev F, Holten Lutzhoft HC, Jorgensen SE. Occurence, fate and effects of pharmaceuticals substance in the environment - A review. Chemosphere. 1998;36(2):357-93.

Heuer $\mathrm{H}$, Schmitt H, Smalla K. Antibiotic resistance gene spread due to manure application on agricultural fields. Curr Opin Microbiol. 2011;14(3):236-43.

Hund-Rinke K, Simon M, Lukow T. Effects of tetracycline on the soil microflora: Function, diversity, resistance. J Soils Sediments. 2004;4(1):11-6.

Jechalke S, Heuer H, Siemens J, Amelung W, Smalla K. Fate and effects of veterinary antibiotics in soil. Trends Microbiol. 2014;22(9):536-45.

Kay P, Blackwell PA, Boxall ABA. Fate of veterinary antibiotics in a macroporous tile drained clay soil. Environ Toxicol Chem. 2004;23:1136-44.

Li B, Zhang T, Xu Z, Fang HHP. Rapid analysis of 21 antibiotics of multiple classes in municipal wastewater using ultra performance liquid chromatographytandem mass spectrometry. Anal Chim Acta. 2009;645(1-2):64-72.

Liu B, Li Y, Zhang X, Wang J, Gao M. Effects of chlortetracycline on soil microbial communities: Comparisons of enzyme activities to the functional diversity via Biolog EcoPlates ${ }^{\text {TM }}$. Eur J Soil Biol. 2015;68:69-76.

Ma T, Pan X, Chen L, Liu W, Christie P, Luo Y. Effects of different concentrations and application frequencies of oxytetracycline on soil enzyme activities and microbial community diversity. Eur J Soil Biol. 2016;76:53-60.

Martinez JL. Environmental pollution by antibiotics and by antibiotic resistance determinants. Environ Pollut. 2009;157(11):2893-902.

Mojica E, Aga DS. Antibiotics pollution in soil and water : potential ecological and human health issues. Encycl Environ Heal. 2011:97-110.

Molaei A, Lakzian A, Haghnia G, Astaraei A, Rasouli-Sadaghiani MH, Ceccherin MT. Assessment of some cultural experimental methods to study the effects of antibiotics on microbial activities in a soil: An incubation study. PLoS One. 2017;12(7):1-14.

Munita JM, Arias C. Mechanisms of antibiotic resistance. HHS Public Access. 2016; 4(2):1-37.

Qingxiang Y, Jing Z, Kongfang Z, Hao Z. Influence of oxytetracycline on the structure and activity of microbial community in wheat rhizosphere soil. J Environ Sci. 2009;21(7):954-9.

Ramaswamy J, Prasher SO, Patel RM, Hussain SA, Barrington SF. The effect of composting on the degradation of a veterinary pharmaceutical. Bioresour Technol. 2010;101(7):2294-9.

Roberts M. Update on acquired tetracycline resistance genes. FEMS Microbiol Lett. 2005;245(2):195-203.

Sarmah AK, Meyer MT, Boxall AB. A global perspective on the use, sales, exposure pathways, occurrence, fate and effects of veterinary antibiotics (VAs) in the environment. Chemosphere. 2006;65(5):725-59.

Sharma VK, Johnson N, Cizmas L, Mcdonald TJ, Kim H. A review of the influence of treatment strategies on antibiotic resistant bacteria and antibiotic resistance genes. Chemosphere. 2016;150:702-14.

Speer B, Shoemaker NB, Salyers AA. Bacterial resistance to tetracycline: mechanisms, transfer, and clinical significance. Clin Microbiol Rev. 1992;5(4): 387-99.

Suzuki S, Ogo M, Koike T, Takada H, Newman B. Sulfonamide and tetracycline resistance genes in total- and culturable-bacterial assemblages in south african aquatic environments. Front Microbiol. 2015;6:1-8.

Thiele-Bruhn S. Pharmaceutical antibiotic compounds in soils - A review. J Plant Nutr Soil Sci. 2003;166(2):145-67.

Thiele-Bruhn S, Beck IC. Effects of sulfonamide and tetracycline antibiotics on soil microbial activity and microbial biomass. Chemosphere. 2005;59(4):457-65.

Tien Y, Li B, Zhang T, Scott A, Murray R, Sabourin L. Impact of dairy manure preapplication treatment on manure composition, soil dynamics of antibiotic resistance genes, and abundance of antibiotic-resistance genes on vegetables at harvest. Sci Total Environ. 2017;581-582:32-9. 
Wang F, Qiao M, Chen Z, Su J, Zhu Y. Antibiotic resistance genes in manureamended soil and vegetables at harvest. J Hazard Mater. 2015;299(3):215-21.

Wang Q, Yates S. Laboratory Study of oxytetracycline degradation kinetics in animal manure and soil. J Agric Food Chem. 2008:56:1683-8.

Xie W-Y, Shen Q, Zhao FJ. Antibiotics and antibiotic resistance from animal manures to soil: a review. Eur J Soil Sci. 2017;69(1):1-15.

Xie WY, Yang XP, Li Q, Wu LH, Shen QR, Zhao FJ. Changes in antibiotic concentrations and antibiotic resistome during commercial composting of animal manures. Environ Pollut. 2016;219:182-90.

Zhang T, Zhang M, Zhang X, Fang HH. Tetracycline resistance genes and tetracycline resistant lactose-fermenting enterobacteriaceae in activated sludge of sewage treatment plants. Environ Sci Technol. 2009;43:3455-60.

Zhang W, Huang M, Qi F, Sun P, Van Ginkel SW. Effect of trace tetracycline concentrations on the structure of a microbial community and the development of tetracycline resistance genes in sequencing batch reactors. Bioresour Technol. 2013;150:9-14.

Zhang YJ, Hu H, Chen Q, Singh B, Yan H, Chen D, He J. Transfer of antibiotic resistance from manure-amended soils to vegetable microbiomes. Environ Int Elsevier. 2019;130:1-10.

Cao J, Wang C, Dou Z, Ji D. Independent and combined effects of oxytetracycline and antibiotic-resistant Escherichia coli $\mathrm{O} 157$ : H7 on soil microbial activity and partial nitrification processes. Soil Biol Biochem. 2016; 98:138-47.

\section{Publisher's Note}

Springer Nature remains neutral with regard to jurisdictional claims in published maps and institutional affiliations.

Ready to submit your research? Choose BMC and benefit from:

- fast, convenient online submission

- thorough peer review by experienced researchers in your field

- rapid publication on acceptance

- support for research data, including large and complex data types

- gold Open Access which fosters wider collaboration and increased citations

- maximum visibility for your research: over $100 \mathrm{M}$ website views per year

At $\mathrm{BMC}$, research is always in progress.

Learn more biomedcentral.com/submissions 